\title{
Use of Phenolic Profile and Fatty Acid Composition on Chemometric Discrimination of Turkish Virgin Olive Oils with Geographical Indication
}

\author{
Çisil Türkay (iD), Onur Özdikicierler (iD) $\square$, Fahri Yemişçioğlu \\ Ege University, Faculty of Engineering, Department of Food Engineering, Bornova, Izmir, Turkey \\ Received (Geliş Tarihi): 19.03.2021, Accepted (Kabul Tarihi): 28.05.2021 \\ $\square$ Corresponding author (Yazışmalardan Sorumlu Yazar): onur.ozdikicierler@ege.edu.tr (O. Özdikicierler) \\ (C) +902323113001/3009 回 +902323114831
}

\begin{abstract}
A geographical indication (Gl) of virgin olive oil (VOO) certifies the origin and production methodology within a determinative quality aspect. On the other hand, from the consumer perspective, VOO's with Gl are expected to show a difference from other VOO's, even though it is not an official obligation. In this study, samples from seven different Turkish VOO's with GI were evaluated and possible discrimination among them was determined and justified using principal component analysis (PCA). Results revealed that saturated fatty acid (SAFA) content was a key factor for Nizip samples to discriminate from VOO's with Gl. Samples of Southern Agean (Güney Ege) and Ayvalık had the highest amount of secoiridoids content. When phenolic profile was considered alone, Mut and Nizip samples were clearly separated while groupings among other samples were somehow overlapped. PCA using fatty acid composition revealed that Nizip and Güney Ege samples were located on different sides of the score plot. Regional distances among sample sets greatly affected the discrimination of the PCA plot when their fatty acid composition was involved.
\end{abstract}

Keywords: Virgin olive oil, Geographical indication, Phenolic compounds, Fatty acid composition, Principal component analysis, Chemometric

\section{Coğrafi İşaretli Türk Zeytinyağlarının Kemometrik Ayırımında Fenolik Profil ve Yağ Asidi Kompozisyonunun Kullanımı}

öz

Coğrafi işaret $(\mathrm{Cl})$, zeytinyağlarında menşei ve üretim metodolojisini belirli bir kalite kapsamı içinde onaylayan bir araçtır. Öte yandan, tüketici açısından bakıldığında, bir Ci'li zeytinyağının Ci olmayan zeytinyağı örneklerinden veya Ci'li diğer zeytinyağlarından farklılık göstermesi beklenmektedir, ancak bu Ci sertifikasyonu için gerekli bir resmi zorunluluk değildir. Bu çalışmada, Cl'li yedi farklı Türk Zeytinyağından alınan numuneler değerlendirilmiş ve bunlar arasındaki olası farklııklar, temel bileşen analizi (PCA) kullanılarak belirlenmiş ve yorumlanmıştır. Sonuçlar, doymuş yağ asidi içeriğinin (SAFA), Nizip örneklerinin diğer zeytinyağlarından ayırt edilmesinde önemli bir faktör olduğunu ortaya koymuştur. Güney Ege ve Ayvalık örneklerinin en yüksek sekoiridoid içeriğine sahip olduğu tespit edilmiştir. Yalnızca fenolik profil ile gerçekleştirilen temel bileşen analizinde (TBA), Mut ve Nizip numuneleri net bir şekilde diğer örnek gruplarından ayrılmışken, diğer örnek grupları örtüşmektedir. Yağ asidi bileşimi ile gerçekleştirilen TBA, Nizip ve Güney Ege örneklerinin skor grafiğinin farklı taraflarında bulunduğunu ortaya çıkarmıştır. Örnek grupları arasındaki 
bölgesel mesafelerin, yağ asit kompozisyonu söz konusu olduğunda PCA'nın ayırt edici sonuçlar vermesinde büyük rol oynağıdı düşünülmektedir.

Anahtar Kelimeler: Zeytinyağı, Coğrafi işaret, Fenolik profili, Yağ asidi kompozisyonu, Temel bileşen analizi, Kemometri

\section{INTRODUCTION}

Olive (Olea europaea L.) belongs to the Oleaceae plant family and it is an olive fruit that is an evergreen tree [1, 2]. Virgin olive oil (VOO) is defined as the oil of the olive fruit produced from the fruit of this tree by mechanical methods without any purification [3, 4]. Through centuries, olive oil has been an important part of Mediterranean cuisine as an icon representing the healthy diet, therefore the consumer demand has been increasing in parallel to its worldwide popularity $[5,6]$.

Most of the VOO content is triacylglycerol esterified with fatty acids, which are the major component (>95\%), and the remaining of this content consists of minor components, such as tocopherols, phenols, sterols, hydrocarbons, and volatile compounds [7-9]. The chemical and sensorial properties of VOO's fluctuate within limits since VOO's do not have a fixed chemical profile. The differences may derive from genetic, agronomic, and environmental factors such as olive variety, growing area, soil, age of trees, maturity index during harvest, pre-processing and post-processing strategies of VOO production [10]. The difference in variety that affects the main chemical and sensorial properties of VOO such as phenolic profile, fatty acid composition, sterol composition, cause significant differentiation between VOO's [11]. The precipitation or irrigation practices of the geographical region where olives are grown, as well as factors such as soil condition, altitude, and climate characteristics, create differences in the chemical composition of VOO. Even VOO's belonging to the same olive variety but grown in different regions were examined, a difference was observed in the sterol, phenolic, and volatile components [12-15].

To meet consumers' demands for originality and quality, producers tend to certify their VOO's based on geographical origin [16]. The geographical indication (Gl) is a sign used on goods that have a specific geographical origin and possess qualities or a reputation that are due to that origin. Besides, geographical indication for VOO not only a useful tool to certify the origin to preserve the interests of rural producers but also helps to protect consumers and producers from economic frauds [17]. In addition, it has a role as a guide to express the identical standards of VOO with GI and support the development of the product quality from the perspective of producers and consumers [18]. Turkish Patent and Trademark Office and European Commission enforce three types of certification labels for geographical indication (GI): protected designation of origin (PDO) and protected geographical indication (PGI). Besides, they may be certified as a traditional specialty guaranteed (TSG) product. For VOO's, PDO or PGI certifications are used in Turkey and European Union. Turkey has 10 different VOO with GI namely; "Ayvalık Zeytinyağı", "Edremit Zeytinyağı", "Güney Ege Zeytinyağı", "Kuzey Ege Zeytinyağı", "Milas Zeytinyağı" and "Mut Zeytinyağı", "Nizip Zeytinyağı", Aydın Memecik Zeytinyağı", "Ödemiş Çekişte Zeytinyağı" and "Burhaniye Zeytinyağı" but only "Milas Zeytinyağı" was registered also the eAmbrosia EU GI registration system $[19,20]$. The geographical regions determined for Turkish VOO's with GI are somehow close or overlapping in some places. Moreover, for some VOO's with $\mathrm{Gl}$ is being produced using same variety, for instance, Ayvalık variety is main variety for Ayvalık Zeytinyağı", "Edremit Zeytinyağı" and "Kuzey Ege Zeytinyağı" while Memecik variety is used for "Güney Ege Zeytinyağı" and "Milas Zeytinyağı". In addition, VOO's with GI not necessarily be monovarietal olive oils, such as Mut VOO's which can be produced using both Gemlik or Ayvalık variaties. Also for most of the GI accepts extraction of $\mathrm{VOO}$ using different producing methods such as pressing or decantation. Moreover, not only extra virgin olive oil (EVOO), but also ordinary VOO's may be certified for same certain Gl's [20]. Therefore, the variation in chemical composition emerged from diversity of variety, VOO extraction techniques and quality criterias make difficult to a reveal the difference in chemical composition of one VOO with $\mathrm{Gl}$ to another in many cases. Moreover, there is not a study in the literature about the evaluation of possible differences in minor compositions of VOO's by taking GI difference as a factor.

Minor characteristics of VOO can be identified through several parameters such as fatty acid composition, phenolic profile, sterol composition, tocopherol composition. In general, chemometric techniques were used to determine possible classifications among VOO sample groups since the difference in multiple variables might be responsible for discrimination. For instance, chemometric techniques were found useful to differentiate EVOO samples according to their geographical origins or variety [14, 21-25].

In this study, seven Turkish VOO's with the geographical indication were studied. General quality characteristics such as free fatty acids (FFA), peroxide value (PV), panisidine value $(\mathrm{p}-\mathrm{anV})$, and specific absorption values (K232 and K270) were determined. Possible 
discriminations among VOO samples were evaluated using Principal component analysis of fatty acid composition (\%) and phenolic profile $(\mathrm{mg} / \mathrm{kg})$ of $\mathrm{VOO}$ samples. Moreover, total monounsaturated fatty acid (MUFA), total polyunsaturated fatty acid (PUFA) and total saturated fatty acid (SAFA) contents were calculated according to fatty acid composition. Total secoiridoids (in $\mathrm{mg} / \mathrm{kg}$ ) were calculated according to identified secoiridoid peaks of the sample phenolic profile. MUFA, SAFA, PUFA, and total secoiridoids were also used in PCA.

\section{MATERIALS and METHODS}

\section{Materials}

Seven different and 5-6 samples from each Turkish VOO's with GI as "Ayvalık Zeytinyağı" (VOO's with GI of Ayvalık region supplied from Ayvalık Chamber of Commerce), "Edremit Zeytinyağı" (VOO's with GI of Edremit region supplied from Edremit Chamber of Commerce), "Güney Ege Zeytinyağı", "Kuzey Ege Zeytinyağı" (VOO's with GI of South Aegean and North Aegean regions supplied from from Taris Olive and Olive Oil Agricultural Sales Cooperatives Union), "Milas Zeytinyağı" (VOO's with GI of Milas region supplied from Milas Chamber of Commerce and Industry), "Mut Zeytinyağı" (VOO's with GI of Mut region supplied from Mut Chamber of Commerce and Industry) and "Nizip Zeytinyağı" (VOO's with GI of Nizip region supplied from Nizip Chamber of Commerce) samples were requested and supplied. Since sample grouping factor is only GI in our study, additional differences emerged from side factors such as varietal and methodological variations are expected. All VOO samples with GI denoted with its regional name as Ayvalık, Edremit, Güney Ege, Kuzey Ege, Milas, Mut and Nizip in the text. The VOO samples were filtrated and filled into glass amber bottles. The headspace was stripped with a gentle stream of nitrogen prior to closing the lids. Samples were kept in in the freezer at $-24^{\circ} \mathrm{C}$ until analyses.

\section{Determination of Quality Characteristics}

\section{Free fatty acid content (FFA)}

The samples were dissolved in diethyl ether and ethanolic solvent and the free fatty acids transferred to the solvent medium were titrated with ethanolic potassium hydroxide solution. The content of free fatty acids according to method COI/T.20/Doc. No 33/Rev.1. and expressed as the free fatty acid percent (\%) in oleic acid [26].

\section{Peroxide Value (PV)}

The peroxide values (PV) of the samples were determined according to the method (PV), COI / T.20 / Doc. No 35 / Rev.1. Samples were dissolved in acetic acid and chloroform and potassium iodide solution was added on them. Released iodine was titrated with sodium thiosulfate solution and results represented as milli-equivalent of active oxygen per kilogram [27].

\section{p-Anisidine Value (p-anV)}

The $p$-anisidine value was determined according to the AOCS-Cd-1890 method. Briefly, isooctane was added to the samples and $5 \mathrm{~mL}$ of this solution was transferred to a separate glass tube prior to $p$-anisidine reactant was added. The absorbance of the sample solutions at $350 \mathrm{~nm}$ measured against the isooctane and the $\mathrm{p}$ anisidine values were calculated. Results were presented as $\mathrm{mmol} / \mathrm{kg}$ oil [28].

\section{Total Oxidation Value (TOTOX)}

TOTOX measures oil deterioration and was calculated from the formula: TOTOX $=2 \mathrm{PV}+p$-anV [28].

\section{Specific Absorptions at Ultraviolet Light}

According to COI / T.20 / Doc. No 19 / Rev.5. samples were dissolved in cyclohexane at a concentration of $1 \%$ $(\mathrm{w} / \mathrm{v})$ and the specific absorption of the samples; It was measured in a $10 \mathrm{~mm}$ cell, at 232 and $270 \mathrm{~nm}$ wavelengths using UV-vis spectrophotometer (Optizen POP spectrometer, K-Lab, South Korea) [29].

\section{Determination of Fatty Acid Composition}

The fatty acid composition of the samples was determined according to the method given in Turkish Food Codex statement number 29181 [30]. $1 \mathrm{~g}$ of sample was weighed and mixed with $2 \mathrm{~mL}$ of heptane. $0.2 \mathrm{~mL}$ of methanolic potassium hydroxide solution was added to this mixture. The supernatant containing the methyl esters was transferred to vials for gas chromatography (GC) injection. The GC oven temperature was kept at the initial temperature of $165^{\circ} \mathrm{C}$ and then increased to $200^{\circ} \mathrm{C}$. The injection block temperature was set to $250^{\circ} \mathrm{C}$ while the detector temperature was set to $280^{\circ} \mathrm{C}$. The flow rate of the carrier gas was $1.2 \mathrm{~mL} / \mathrm{min}$ and $1 \mu \mathrm{L}$ of the sample was injected. After all the peaks were obtained and identified, the peak areas were presented as percentages.

\section{Determination of Phenolic Profile}

According to COI/T.20/Doc. No 29/Rev.1method, minor polar phenolic compounds were extracted and their quantities were determined by high-pressure liquid chromatography (HPLC) [31]. HPLC (Agilent 1260 model infinity II, USA) was equipped with a Spherisorb ODS-2 C18 reverse-phase column $(4.6 \mathrm{~mm} \times 25 \mathrm{~cm})$, $100 \mathrm{~A}^{\circ}$ spectrophotometric UV detector, and integrator at $280 \mathrm{~nm}$. According to the method, $2 \mathrm{~g}$ 's of the sample 
was weighed into glass tubes and $1 \mathrm{~mL}$ internal standard solution was added. After mixing with vortex for 30 seconds, $5 \mathrm{~mL}$ of methanol/water $80 / 20(\mathrm{v} / \mathrm{v})$ solution was added. The samples were kept in an ultrasonic bath for 15 minutes and centrifuged at $5000 \mathrm{revs} / \mathrm{min}$ for 25 minutes. For HPLC, the flow rate of mobile phases; methanol, acetonitrile, and orthophosphoric acid $99.8 \%$ $(\mathrm{v} / \mathrm{v})$ was $0.8 \mathrm{~mL} / \mathrm{min}$ with a gradient flow composition. The injection volume was $40 \mu \mathrm{L}$ and the peak areas were calculated with respect to the area of internal standard peak (syringic acid). The respective response factor (RRF value) was found to be 4.7 (the ratio of the response factor of syringic acid to tyrosol). The amounts of polar phenolic compounds are expressed in $\mathrm{mg} / \mathrm{kg}$ oil as tyrosol equivalent.

\section{Statistical Analysis and Chemometric Method}

All analyses were duplicated, and measurements were triplicated to ensure the accuracy of the results. ANOVA and Tukey's post-hoc test at a significance level of $\% 5$ $(\alpha=0.05)$ was applied using IBM SPSS 25 to evaluate differences in quality characteristics of VOO samples with Gl. Three different principal component analyses were carried out using Unscrambler X (Camo Analytics, Norway) to visualize possible discriminations among VOO samples with Gl. Fatty acid composition and phenolic profile data were mean-centered and randomized, leverage correction method was used for internal validation. All values were weighted as reciprocal of the standard deviation to eliminate the size difference effect on the results. The singular value decomposition (SVD) algorithm was selected to build the PCA model. No rotation applied. The first two PC's were visualized on two-dimensional biplots to determine the discrimination on the score plots. PCA analysis of the fatty acid composition, phenolic profile, and fatty acid composition + phenolic profile data were presented separately.

\section{RESULTS and DISCUSSION}

The approximate regions of seven different Turkish VOO's with Gl used in our study given in Figure 1. Within the process of our work, three new VOO's registered with GI by the Turkish Patent and Trademark Office, namely "Ödemiş Çekişte Zeytinyağı" (Ödemiş Çekişte VOO), "Aydın Memecik Zeytinyağı" (Aydın Memecik VOO) and "Burhaniye Zeytinyağı" (Burhaniye VOO) but not took a part in our study. Slight overlaps or close regions for Edremit Zeytinyağı, Ayvalık Zeytinyağı and Kuzey Ege Zeytinyağı in the northern Aegean region and Güney Ege Zeytinyağı and Milas Zeytinyağı may be mentioned. Since minor characteristics such as phenolic profile and fatty acid composition are generally affected by region and variety, among these samples tough discrimination may be expected at multivariate analysis.

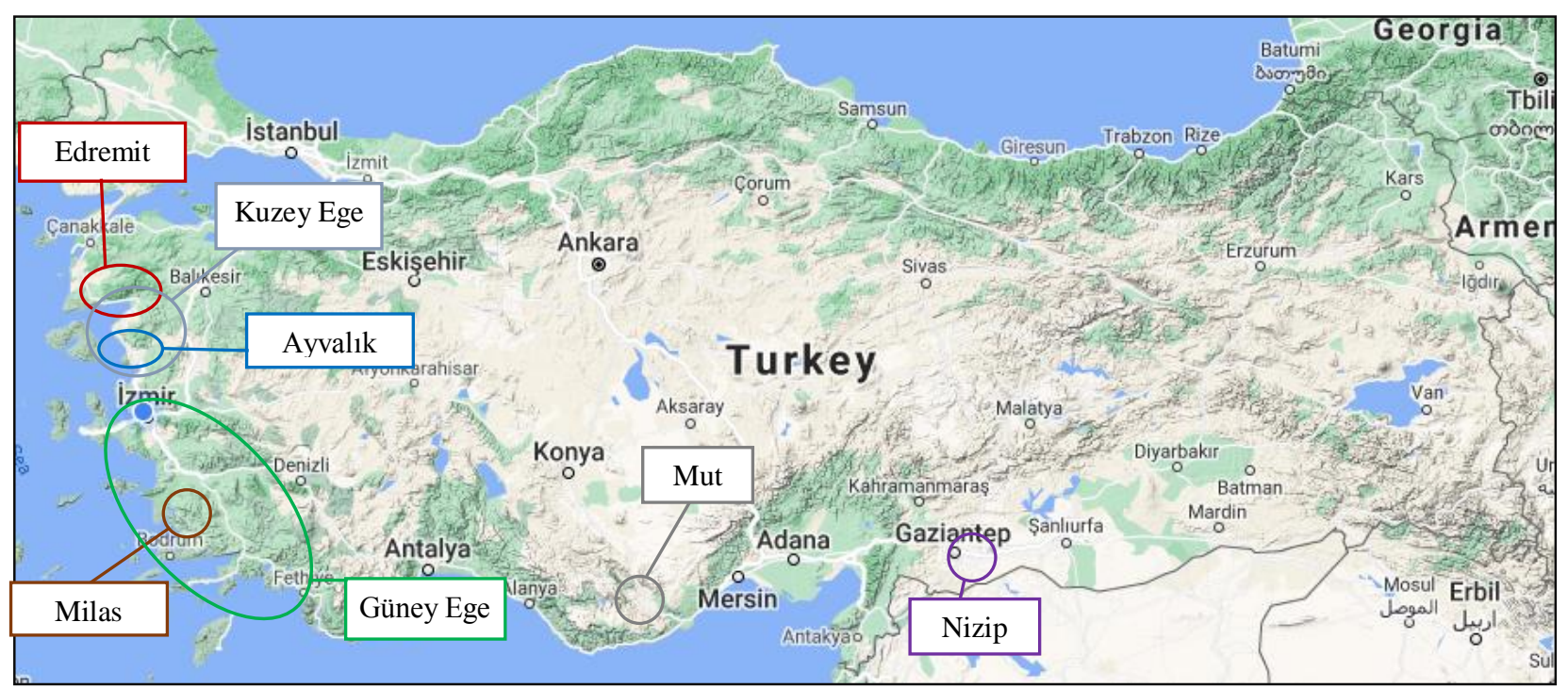

Figure 1. The map of approximate geographical regions of Turkish virgin olive oils with geographical identification used in our study as declared official dossiers, coloring was matched with principal component analysis score plot groupings (Maps image of Turkey was used courtesy of Google LLC). 
Table 1. Quality characteristics of virgin olive oils with geographical identification

\begin{tabular}{|c|c|c|c|c|c|c|}
\hline $\begin{array}{l}\text { Virgin olive oils } \\
\text { with geographical } \\
\text { identification }\end{array}$ & $\begin{array}{l}\text { Free fatty } \\
\text { acid content } \\
\text { (\% oleic acid) } \\
(\mathrm{P}=0.076)\end{array}$ & $\begin{array}{l}\text { Peroxide } \\
\text { value } \\
\left(\mathrm{meq} \mathrm{O}_{2} / \mathrm{kg}\right) \\
(\mathrm{P}=0.641)\end{array}$ & $\begin{array}{l}p \text {-anisidine } \\
\text { value } \\
\text { (mmol/kg) } \\
(\mathrm{P}<0.000)\end{array}$ & $\begin{array}{l}\text { Total oxidation } \\
\text { value } \\
(P=0.024)\end{array}$ & $\begin{array}{l}\text { K232 } \\
(P<0.000)\end{array}$ & $\begin{array}{l}\text { K270 } \\
(P<0.000)\end{array}$ \\
\hline Ayvalık & & $10.65(4.65)$ & $17.54^{\mathrm{ab}}(1.07)$ & $38.84^{\mathrm{ab}}(9.61)$ & $1.566^{\mathrm{a}}(0.260)$ & $0.098^{a}(0.013)$ \\
\hline & 20) & & $15.18^{\mathrm{a}}(5.36)^{\prime}$ & 82) & $(0.093)$ & $0.106^{\mathrm{ab}}(0.011)$ \\
\hline & & & $4.71)$ & & & \\
\hline Kuzey Ege & $48(0.20)$ & $8.74(2.47)$ & $11.64^{\mathrm{a}}(2.67)$ & $29.11^{a}(5.08)$ & $1.825^{\mathrm{ab}}(0.1$ & $0.089^{a}(0.010)$ \\
\hline Milas & & $10.98(5.87)$ & $15.99^{\mathrm{a}}(7.92)$ & $37.95^{\mathrm{ab}}(8.27)$ & $2.188^{\circ}(0.287)$ & $0.133^{b}(0.051)$ \\
\hline Mut & & & $13.10^{\mathrm{a}}(2.17)$ & & $1.803^{\mathrm{ab}}(0.130)$ & $0.093^{a}(0.017)$ \\
\hline Nizip & $0.43(0.23)$ & $11.10(5.18)$ & $22.66^{\mathrm{b}}(5.29)$ & $44.86^{b}(10.62)$ & $1.771^{\mathrm{ab}}(0.136)$ & $0.117^{\mathrm{ab}}(0.018)$ \\
\hline
\end{tabular}

The mean values were given with standard deviation (in parenthesis). Letters indicate the statistical grouping according to Tukey's post-hoc test along with columns. Significance $(P)$ values of ANOVA for each variable were presented in the first row within parenthesis.

FFA content is an indication for hydrolysis reaction in oils, and during the progress of hydrolysis reaction, FFA content increases while quality decreases. According to the FFA contents given in Table 1, there was no statistical difference between samples $(P=0.076)$. FFA values varied between 0.19 and 0.52 . The $P V$ and $p$ anV are quality parameters that express the oxidation degree while providing information about the oxidative deterioration and approximate storage time of the oil. According to the PV's, there was no statistical difference between samples, and the values varied between 9.74 and $12.98 \quad(P=0.641)$. Worth to mention that the standard deviation is an expression of the variation in a value between different VOO samples with same GI. Therefore, if standard deviation is relatively high, the variation in that particular quality aspect is high between different VOO's produced within that geographical region. For instance, notable high standard deviations in PV implies that different VOO's with same GI has different oxidation reaction degrees. This may be emerged from variability in process methods practiced by VOO producers in that geographical region.

No statistical difference is observed between $p$-anV of Ayvalık, Edremit, Güney Ege, Kuzey Ege, Milas, Mut samples while $p$-anV of Nizip (22.661) was statistically higher than the others. TOTOX values of Ayvalık, Edremit, Güney Ege, Kuzey Ege, Milas, Mut VOO's showed no statistical difference. Specific absorption values are an indicator of the quality changes that may occur during the storage and processing stages of VOO. In general, specific absorption at $232 \mathrm{~nm}$ increases with diene conjugation and primary oxidation products, while absorption at $270 \mathrm{~nm}$ increases with triene conjugation and secondary oxidation products. K232 values of Ayvalık, Kuzey Ege, Mut, Nizip VOO's showed no statistical difference while K232 values of Edremit, Güney Ege, Kuzey Ege, Mut, Nizip VOO's were assigned in a different statistical group. Similar statistical Tukey groupings may be observed for K270 values.

Phenolic profile was identified by matching respective retention times with the standard IOC method and standardized chromatograms of a previous study [32].
Unidentified peaks did not included in the chemometric analysis. A sample RP-HPLC chromatogram can be seen in Figure 2 acquired in our study. From simple phenols, 3,4-DHPEA (tyrosol), p-HPEA (hydroxytyrosol), and $p$-coumaric acid were quantified. Pinoresinol was only lignan and 3,4-DHPEA-EDA (oleacein), p-HPEAEDA (oleocanthal), 3,4-DHPEA-EA (oleuropein aglycone monoaldehyde), and p-HPEA-EA (lignostride aglycone monoaldehyde) were determined as VOO secoiridoids as given in Table 2. Different phenolic compounds were identified in different studies with Turkish VOO's in the literature. According to a previous study, $p$-coumaric acid content of commercial VOO's from the Aegean region ranged between $0.10-0.69 \mathrm{mg} / \mathrm{kg}$ while samples obtained from the Çanakkale region and same season contain between 2.0-4.3 $\mathrm{mg} / \mathrm{kg}$ p-coumaric acid. Pinoresinol, which is a characteristic lignan in VOO's as reported in many studies, was not reported in some studies about the phenolic profile of VOO's [7]. This may be justified with two possible reasons. First; minor uncertainties in the chromatogram may be caused by some misidentifications. Second, the seasonal, regional, and varietal changes are greatly affective on the phenolic profile as suggested by Alkan et al. [13].

Amounts of 3,4-DHPEA in VOO samples with Gl varied between 6.2 and $2.4 \mathrm{mg} / \mathrm{kg}$. Güney Ege samples contained the highest $p$-HPEA value $(6.9 \mathrm{mg} / \mathrm{kg})$. $p$ coumaric acid varied between 0.5 and $4.8 \mathrm{mg} / \mathrm{kg}$ in our samples and Kuzey Ege samples have the highest $p$ coumaric acid content $(4.8 \mathrm{mg} / \mathrm{kg})$. Güney Ege samples contained the highest $(83.9 \mathrm{mg} / \mathrm{kg})$ pinoresinol content. Amounts of 3,4-DHPEA-EDA were between 15.5 and $66.6 \mathrm{mg} / \mathrm{kg}$, Ayvalık samples were richest in 3,4DHPEA-EDA content. 3,4-DHPEA-EA was between 13.9 and $31.9 \mathrm{mg} / \mathrm{kg}$ in VOO samples. The amounts of p-HPEA-EA varied between 2.8 and $7.7 \mathrm{mg} / \mathrm{kg}$. When the total amount of secoiridoids was considered, Ayvalık samples contain $111.4 \mathrm{mg} / \mathrm{kg}$ of secoiridoids while Kuzey Ege samples contained $38.6 \mathrm{mg} / \mathrm{kg}$. 


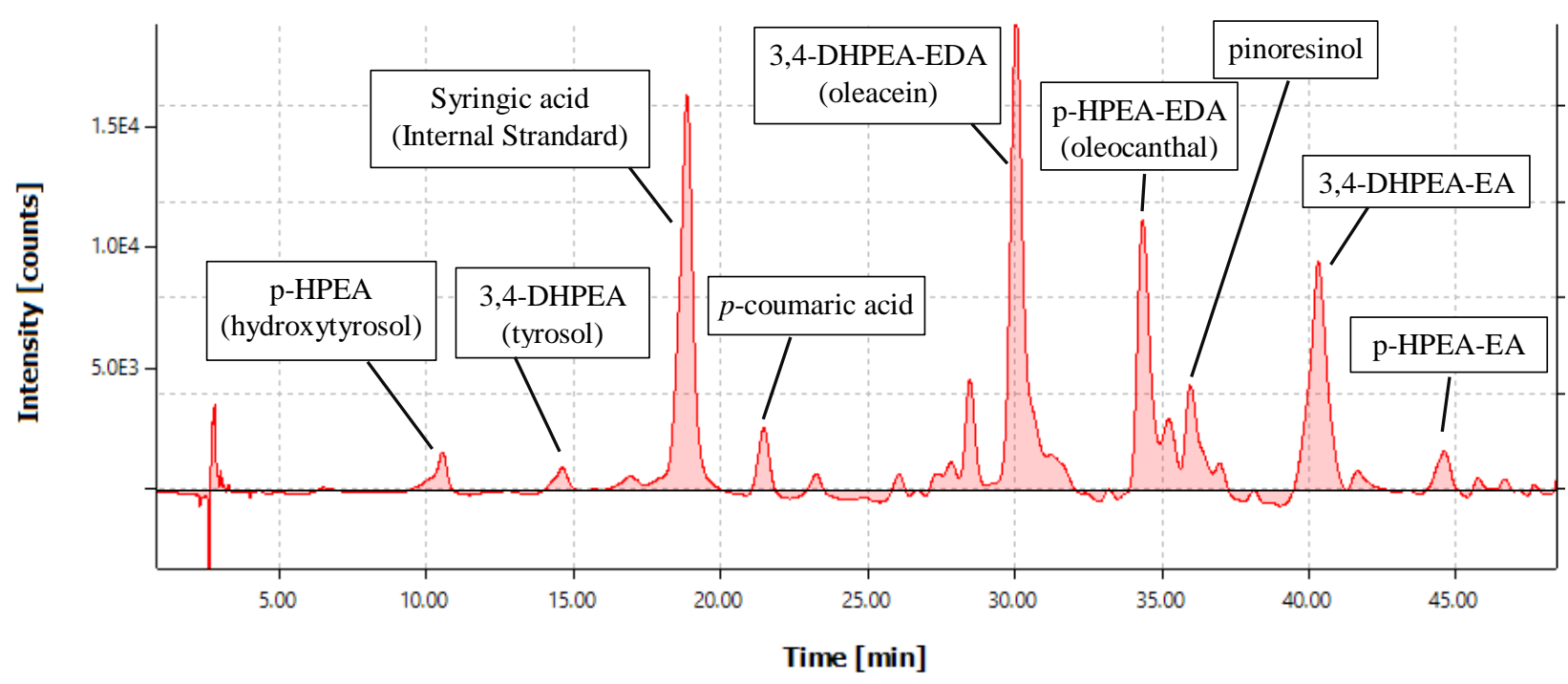

Figure 2. A sample chromatogram for phenolic profile of Edremit Zeytinyağı sample. 3,4-DHPEA-EA: oleuropein aglycone monoaldehyde, p-HPEA-EA: lignostride aglycone monoaldehyde

Table 2. Phenolic profile of Turkish virgin olive oils with geographical identification

\begin{tabular}{|c|c|c|c|c|c|c|c|c|}
\hline & \multirow[b]{2}{*}{ Phenolics (mg/kg) } & \multicolumn{7}{|c|}{ Turkish virgin olive oils with geographical identification * } \\
\hline & & Ayvalık & Edremit & $\begin{array}{l}\text { Güney } \\
\text { Ege }\end{array}$ & $\begin{array}{l}\text { Kuzey } \\
\text { Ege }\end{array}$ & Milas & Mut & Nizip \\
\hline & $\begin{array}{l}\text { 3,4-DHPEA } \\
\text { (tyrosol) }\end{array}$ & $\begin{array}{c}4.1 \\
(2.5)\end{array}$ & $\begin{array}{c}2.9 \\
(2.3)\end{array}$ & $\begin{array}{c}3.4 \\
(1.4)\end{array}$ & $\begin{array}{l}2.8 \\
(1)\end{array}$ & $\begin{array}{c}6.2 \\
(3.8)\end{array}$ & $\begin{array}{c}2.4 \\
(0.4)\end{array}$ & $\begin{array}{l}3.1 \\
(1)\end{array}$ \\
\hline \multirow[t]{2}{*}{$\begin{array}{l}\text { Simple } \\
\text { Phenols }\end{array}$} & $\begin{array}{l}p \text {-HPEA } \\
\text { (hydroxytyrosol) }\end{array}$ & $\begin{array}{l}2.7 \\
(1.6)\end{array}$ & $\begin{array}{l}2.8 \\
(2.3)\end{array}$ & $\begin{array}{c}6.9 \\
(1.3)\end{array}$ & $\begin{array}{c}4 \\
(0.8)\end{array}$ & $\begin{array}{c}5 \\
(1.6)\end{array}$ & $\begin{array}{l}3.3 \\
(0.3)\end{array}$ & $\begin{array}{c}3.4 \\
(1.4)\end{array}$ \\
\hline & $p$-coumaric acid & $\begin{array}{c}3.9 \\
(1.8)\end{array}$ & $\begin{array}{c}3.9 \\
(1.3)\end{array}$ & $\begin{array}{l}2.2 \\
(0.9)\end{array}$ & $\begin{array}{c}4.8 \\
(2.3)\end{array}$ & $\begin{array}{c}2.9 \\
(1.7)\end{array}$ & $\begin{array}{l}0.9 \\
(0)\end{array}$ & $\begin{array}{c}0.5 \\
(0.5)\end{array}$ \\
\hline \multirow[t]{3}{*}{ Lignan } & Pinoresinol & $\begin{array}{l}9.2 \\
(4.8)\end{array}$ & $\begin{array}{l}6.8 \\
(0.7)\end{array}$ & $\begin{array}{c}8.2 \\
(0.6)\end{array}$ & $\begin{array}{c}6.4 \\
(2.3)\end{array}$ & $\begin{array}{l}19.7 \\
(6.1)\end{array}$ & $\begin{array}{l}9.8 \\
(1.8)\end{array}$ & $\begin{array}{c}6.4 \\
(2.5)\end{array}$ \\
\hline & $\begin{array}{l}\text { 3,4-DHPEA-EDA } \\
\text { (oleacein) }\end{array}$ & $\begin{array}{l}66.6 \\
(6.9)\end{array}$ & $\begin{array}{c}30.2 \\
(12.2)\end{array}$ & $\begin{array}{l}52.3 \\
(20)\end{array}$ & $\begin{array}{l}15.5 \\
(4.6)\end{array}$ & $\begin{array}{l}41.2 \\
(2.1)\end{array}$ & $\begin{array}{c}19.6 \\
(1)\end{array}$ & $\begin{array}{c}19 \\
(10.6)\end{array}$ \\
\hline & $\begin{array}{l}p \text {-HPEA-EDA } \\
\text { (oleocanthal) }\end{array}$ & $\begin{array}{c}39.7 \\
(13.8)\end{array}$ & $\begin{array}{l}24.9 \\
(5.6)\end{array}$ & $\begin{array}{l}83.9 \\
(5.2)\end{array}$ & $\begin{array}{l}25.6 \\
(2.3)\end{array}$ & $\begin{array}{c}44.4 \\
(17.5)\end{array}$ & $\begin{array}{l}31.9 \\
(1.6)\end{array}$ & $\begin{array}{c}39.9 \\
(7)\end{array}$ \\
\hline \multirow[t]{3}{*}{ Secoiridoids } & $\begin{array}{l}\text { 3,4-DHPEA-EA } \\
\text { (oleuropein } \\
\text { aglycone } \\
\text { monoaldehyde) } \\
p \text {-HPEA-EA }\end{array}$ & $\begin{array}{l}31.9 \\
(6.8)\end{array}$ & $\begin{array}{l}19.5 \\
(4.5)\end{array}$ & $\begin{array}{l}21.1 \\
(3.8)\end{array}$ & $\begin{array}{c}13.9 \\
(3)\end{array}$ & $\begin{array}{l}18.4 \\
(8.9)\end{array}$ & $\begin{array}{l}28.6 \\
(1.8)\end{array}$ & $\begin{array}{c}28 \\
(2.4)\end{array}$ \\
\hline & $\begin{array}{l}\text { (lignostride } \\
\text { aglycone } \\
\text { monoaldehyde) }\end{array}$ & $\begin{array}{l}3.8 \\
(0.7)\end{array}$ & $\begin{array}{c}3.4 \\
(0.5)\end{array}$ & $\begin{array}{c}7.1 \\
(1.9)\end{array}$ & $\begin{array}{l}2.8 \\
(0.5)\end{array}$ & $\begin{array}{l}3.6 \\
(0.9)\end{array}$ & $\begin{array}{l}7.7 \\
(0.9)\end{array}$ & $\begin{array}{c}9.2 \\
(2.9)\end{array}$ \\
\hline & Total secoiridoids & $\begin{array}{l}111.4 \\
(16.1)\end{array}$ & $\begin{array}{c}59.9 \\
(16.6)\end{array}$ & $\begin{array}{c}94.4 \\
(20.4)\end{array}$ & $\begin{array}{l}38.6 \\
(8.3)\end{array}$ & $\begin{array}{c}82.9 \\
(7)\end{array}$ & $\begin{array}{l}65.7 \\
(2.3)\end{array}$ & $\begin{array}{c}62.6 \\
(12.5)\end{array}$ \\
\hline
\end{tabular}

* The mean values were given with standard deviation (in parenthesis). 
Ç. Türkay, O. Özdikicierler, F. Yemişçioğlu Akademik Gıda 19(2) (2021) 126-136

Table 3. Fatty acid composition of Turkish virgin olive oils with geographical identification

\begin{tabular}{|c|c|c|c|c|c|c|c|}
\hline & \multicolumn{7}{|c|}{ Geographical Identification * } \\
\hline Fatty Acids (\%) & Ayvalık & Edremit & Güney Ege & Kuzey Ege & Milas & Mut & Nizip \\
\hline $\begin{array}{l}\text { C16:0 } \\
\text { (palmitic acid) }\end{array}$ & $\begin{array}{l}14.3 \\
(0.5)\end{array}$ & $\begin{array}{l}15.5 \\
(0.6)\end{array}$ & $\begin{array}{l}13.4 \\
(0.4)\end{array}$ & $\begin{array}{l}13.9 \\
(0.6)\end{array}$ & $\begin{array}{l}14.6 \\
(0.7)\end{array}$ & $\begin{array}{l}15.2 \\
(0.7)\end{array}$ & $\begin{array}{c}15 \\
(0.5)\end{array}$ \\
\hline $\begin{array}{l}\text { C16:1 } \\
\text { (palmitoleic acid) }\end{array}$ & $\begin{array}{c}0.9 \\
(0.1)\end{array}$ & $\begin{array}{c}0.9 \\
(0.1)\end{array}$ & $\begin{array}{l}1 \\
(0)\end{array}$ & $\begin{array}{c}1 \\
(0.1)\end{array}$ & $\begin{array}{c}1.3 \\
(0.1)\end{array}$ & $\begin{array}{l}1.2 \\
(0.2)\end{array}$ & $\begin{array}{l}1.1 \\
(0.1)\end{array}$ \\
\hline $\begin{array}{l}\text { C17:0 } \\
\text { (margaric acid) }\end{array}$ & $\begin{array}{l}0.1 \\
(0)\end{array}$ & $\begin{array}{l}0.1 \\
(0)\end{array}$ & $\begin{array}{c}0 \\
(0)\end{array}$ & $\begin{array}{l}0.1 \\
(0)\end{array}$ & $\begin{array}{l}0.1 \\
(0)\end{array}$ & $\begin{array}{l}0.1 \\
(0)\end{array}$ & $\begin{array}{l}0.1 \\
(0)\end{array}$ \\
\hline $\begin{array}{l}\text { C17:1 } \\
\text { (margoleic acid) }\end{array}$ & $\begin{array}{l}0.2 \\
(0)\end{array}$ & $\begin{array}{l}0.2 \\
(0)\end{array}$ & $\begin{array}{l}0.1 \\
(0)\end{array}$ & $\begin{array}{l}0.2 \\
(0)\end{array}$ & $\begin{array}{c}0.2 \\
(0.1)\end{array}$ & $\begin{array}{c}0.1 \\
(0.1)\end{array}$ & $\begin{array}{l}0.2 \\
(0)\end{array}$ \\
\hline $\begin{array}{l}\text { C18:0 } \\
\text { (stearic acid) }\end{array}$ & $\begin{array}{l}2.6 \\
(0.2)\end{array}$ & $\begin{array}{l}2.5 \\
(0.1)\end{array}$ & $\begin{array}{l}2.6 \\
(0.1)\end{array}$ & $\begin{array}{l}2.6 \\
(0.1)\end{array}$ & $\begin{array}{l}2.8 \\
(0.2)\end{array}$ & $\begin{array}{l}2.5 \\
(0.4)\end{array}$ & $\begin{array}{l}4.1 \\
(0.4)\end{array}$ \\
\hline $\begin{array}{l}\text { C18:1 } \\
\text { (oleic acid) }\end{array}$ & $\begin{array}{l}70.3 \\
(0.5)\end{array}$ & $\begin{array}{l}69.5 \\
(0.8)\end{array}$ & $\begin{array}{l}71.3 \\
(0.7)\end{array}$ & $\begin{array}{l}70.2 \\
(1.4)\end{array}$ & $\begin{array}{l}70.1 \\
(2.2)\end{array}$ & $\begin{array}{l}69.4 \\
(1.5)\end{array}$ & $\begin{array}{c}68 \\
(1.7)\end{array}$ \\
\hline $\begin{array}{l}\text { C18:2 } \\
\text { (linoleic acid) }\end{array}$ & $\begin{array}{l}10.1 \\
(0.3)\end{array}$ & $\begin{array}{c}9.6 \\
(0.3)\end{array}$ & $\begin{array}{l}10.1 \\
(0.8)\end{array}$ & $\begin{array}{l}10.4 \\
(0.8)\end{array}$ & $\begin{array}{l}9.5 \\
(2.1)\end{array}$ & $\begin{array}{c}9.9 \\
(1.7)\end{array}$ & $\begin{array}{c}9.7 \\
(1.1)\end{array}$ \\
\hline $\begin{array}{l}\text { C20:0 } \\
\text { (arachidic acid) }\end{array}$ & $\begin{array}{l}0.4 \\
(0)\end{array}$ & $\begin{array}{l}0.4 \\
(0)\end{array}$ & $\begin{array}{l}0.4 \\
(0)\end{array}$ & $\begin{array}{l}0.4 \\
(0)\end{array}$ & $\begin{array}{l}0.4 \\
(0)\end{array}$ & $\begin{array}{l}0.4 \\
(0)\end{array}$ & $\begin{array}{l}0.6 \\
(0)\end{array}$ \\
\hline $\begin{array}{l}\text { C18:3 } \\
\text { (linolenic acid) }\end{array}$ & $\begin{array}{l}0.6 \\
(0)\end{array}$ & $\begin{array}{l}0.6 \\
(0)\end{array}$ & $\begin{array}{l}0.7 \\
(0)\end{array}$ & $\begin{array}{l}0.6 \\
(0)\end{array}$ & $\begin{array}{l}0.7 \\
(0.1)\end{array}$ & $\begin{array}{l}0.7 \\
(0.1)\end{array}$ & $\begin{array}{l}0.7 \\
(0)\end{array}$ \\
\hline $\begin{array}{l}\text { C20:1 } \\
\text { (gadoleic acid) }\end{array}$ & $\begin{array}{l}0.3 \\
(0)\end{array}$ & $\begin{array}{l}0.3 \\
(0)\end{array}$ & $\begin{array}{c}0.3 \\
(0.1)\end{array}$ & $\begin{array}{l}0.3 \\
(0)\end{array}$ & $\begin{array}{l}0.3 \\
(0)\end{array}$ & $\begin{array}{l}0.3 \\
(0)\end{array}$ & $\begin{array}{l}0.3 \\
(0)\end{array}$ \\
\hline $\begin{array}{l}\text { C22:0 } \\
\text { (behenic acid) }\end{array}$ & $\begin{array}{l}0.1 \\
(0)\end{array}$ & $\begin{array}{l}0.1 \\
(0)\end{array}$ & $\begin{array}{l}0.1 \\
(0.1)\end{array}$ & $\begin{array}{l}0.1 \\
(0)\end{array}$ & $\begin{array}{l}0.1 \\
(0)\end{array}$ & $\begin{array}{l}0.1 \\
(0)\end{array}$ & $\begin{array}{l}0.2 \\
(0)\end{array}$ \\
\hline $\begin{array}{l}\text { C24:0 } \\
\text { (lignoseric acid) }\end{array}$ & $\begin{array}{l}0.1 \\
(0)\end{array}$ & $\begin{array}{l}0.1 \\
(0)\end{array}$ & $\begin{array}{l}0.1 \\
(0)\end{array}$ & $\begin{array}{l}0.1 \\
(0)\end{array}$ & $\begin{array}{l}0.1 \\
(0)\end{array}$ & $\begin{array}{l}0.1 \\
(0)\end{array}$ & $\begin{array}{l}0.1 \\
(0)\end{array}$ \\
\hline $\begin{array}{l}\sum \text { MUFA } \\
\text { (monounsaturated } \\
\text { fatty acids) }\end{array}$ & $\begin{array}{l}71.7 \\
(0.4)\end{array}$ & $\begin{array}{c}71 \\
(0.8)\end{array}$ & $\begin{array}{l}73.4 \\
(2.2)\end{array}$ & $\begin{array}{l}71.7 \\
(1.3)\end{array}$ & $\begin{array}{l}71.8 \\
(2.3)\end{array}$ & $\begin{array}{c}71 \\
(1.7)\end{array}$ & $\begin{array}{l}69.5 \\
(1.6)\end{array}$ \\
\hline $\begin{array}{l}\sum \text { PUFA } \\
\text { (polyunsaturated } \\
\text { fatty acids) }\end{array}$ & $\begin{array}{l}10.7 \\
(0.3)\end{array}$ & $\begin{array}{l}10.2 \\
(0.3)\end{array}$ & $\begin{array}{l}10.8 \\
(0.8)\end{array}$ & $\begin{array}{c}11 \\
(0.8)\end{array}$ & $\begin{array}{l}10.1 \\
(2.2)\end{array}$ & $\begin{array}{l}10.6 \\
(1.8)\end{array}$ & $\begin{array}{l}10.4 \\
(1.1)\end{array}$ \\
\hline $\begin{array}{l}\sum \text { SAFA } \\
\text { (saturated fatty } \\
\text { acids) }\end{array}$ & $\begin{array}{l}17.6 \\
(0.4)\end{array}$ & $\begin{array}{l}18.8 \\
(0.5)\end{array}$ & $\begin{array}{l}16.7 \\
(0.4)\end{array}$ & $\begin{array}{l}17.3 \\
(0.5)\end{array}$ & $\begin{array}{l}18.1 \\
(0.6)\end{array}$ & $\begin{array}{l}18.4 \\
(0.6)\end{array}$ & $\begin{array}{l}20.1 \\
(0.7)\end{array}$ \\
\hline
\end{tabular}

The fatty acid composition values of VOO's with GI were given in Table 3 . The major fatty acid in VOO is oleic acid (C18:1). According to the results, oleic acid varied between $68 \%$ and $71.3 \%$ in samples. It has been determined that the oleic acid percentage of Edremit, Nizip, and Mut VOO's is below $70 \%$ while the rest of the samples have oleic acid content above $70 \%$. Güney Ege samples had the highest oleic acid content (71.3\%). Another major fatty acid is palmitic acid (C16:0) for VOO's. Palmitic acid varied between $13.4 \%$ and $15.5 \%$ in whole VOO samples. Ayvalık, Edremit, Milas, Mut, Nizip samples contain more than $14 \%$ of palmitic acid according to the findings. Stearic acid (C18:0) content, which is another major fatty acid for VOO's varied between $2.5 \%$ and $4.1 \%$. Nizip VOO's appear to have the highest stearic acid content $(4.1 \%)$. When the linoleic acid values were examined, it was found that it varied between $9.5 \%$ and $10.4 \%$. SAFA
(C16:0+C17:0+C18:0+C20:0+C22:0+C24:0), MUFA (C16:1+C17:1+C18:1+C20:1), PUFA (C18:2+C18:3) contents of the samples were determined according to the fatty acid compositions. MUFA values varied between $69.5 \%$ and $73.4 \%$ while SAFA content was between $16.7 \%$ and $20.1 \%$. In a previous study; VOO's of Ayvalık variety produced from the north Aegean region were found to contain approximately $2.3 \%$ and $4.2 \%$ stearic acid (C18:0) likewise in our study [33]. Gurdeniz et al. found that virgin Memecik VOO of the İzmir region had approximately $71.2 \%$ oleic acid content which is a similar result to our study [23]. However, in another study about the characterization of the arbequina variety EVOO's grown in the Aegean region, it was indicated that oleic acid content was found to be lower, as $65 \%$ [34]. Therefore, not only the geographical region of the VOO but also variety a strong determinative factor for fatty acid composition. On the 
other hand, linoleic acid and palmitic acid levels of Nizip Yağlık, Ayvalık, Kilis Yağık, Halhalı, Karamani varieties from southeastern Anatolia were around $10.90 \%$ and
$14.56 \%$, respectively, which was similar to our results [35].
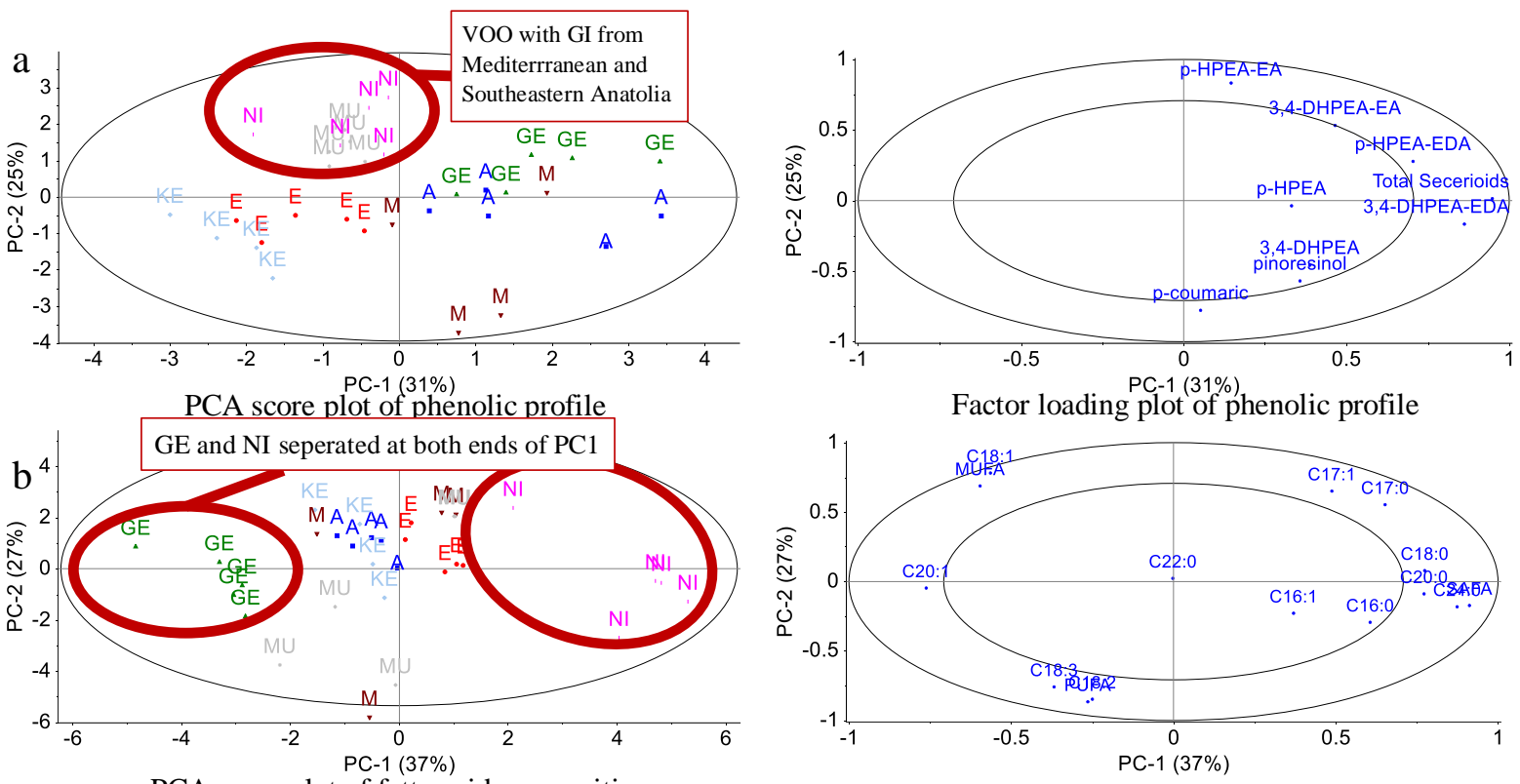

PCA score plot of fatty acid composition

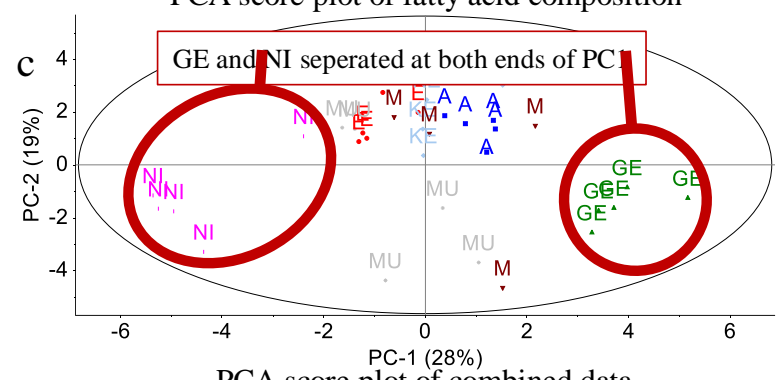

Factor loading plot of fatty acid composition

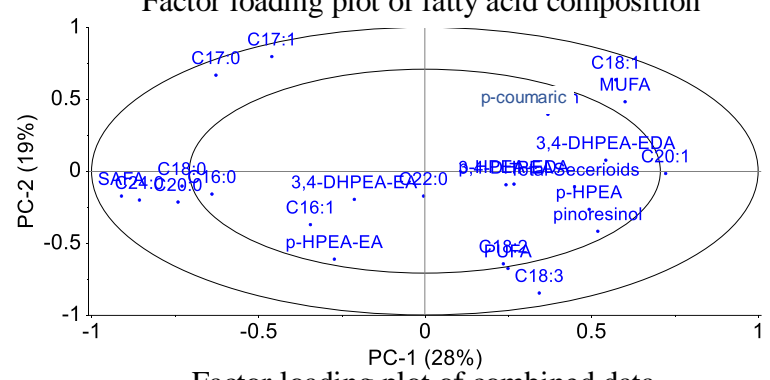

Factor loading plot of combined data

Figure 3. PCA score and loading plots for phenolic profile data (a), fatty acid composition data (b), and phenolic profile + fatty acid composition data combined (c). Ayvalık, Edremit, Güney Ege, Kuzey Ege, Milas Zeytinyağı, Mut and Nizip samples were abbreviated on plots as; A, E, GE, KE, M, MU, NI, respectively.

PCA is a non-biased multivariate analysis, that visualizes discrimination between samples on a reduced factor space. Labeling or coloring sample groups on PCA score plot gives explanative information about possible discrimination between sample groups. Figure 3 represents PCA score and loading plots for phenolic profile data, fatty acid composition, and phenolic profile + fatty acid composition (combined). $\mathrm{MU}$ and $\mathrm{NI}$ samples separated along PC2 of phenolic profile PCA score plot and located at positive region vertically (Figure 3a). The difference in the geographical region and possible climate conditions may be responsible for this separation from $\mathrm{OO}$ samples of the Aegean region. According to the official dossiers, NI was produced from "Nizip Yağlık" olives, while MU was produced from Gemlik and Ayvalık varieties. Therefore, this separation of $\mathrm{NI}$ and $\mathrm{MU}$ together from other samples, which are generally Ayvalık and Memecik olives, cannot be justified by varietal difference. According to the absolute loadings of the variables, p-HPEA-EA has 0.8347 on PC2, which implies that p-HPEA-EA was a determinative factor for the separation of the samples along the PC2 axis. According to the Box-plots given in Figure 4b, p-HPEA-EA content of $\mathrm{NI}$, MU, and GE samples were higher than other samples. In addition, the separation of GE and KE samples of phenolic profile PCA can be associated with the varietal and geographical differences in samples. Total secoiridoids, 3,4-DHPEA-EDA, p-HPEA-EDA were the main responsible variables for the separation of the samples along the PC1 axis according to their loadings $(0.9485$, $0.8632,0.7044$, respectively). Also, total secoiridoids content was low in KE samples but high in A and GE samples as seen in Figure 4. Phenolic composition determined as a discriminative factor for South Aegean and North Aegean VOO's in a previous study [13]. 
Although a good separation between sample groups was not noted on the score plot of fatty acid composition PCA, a separation between GE and NI samples along the $P C 1$ axis may be observed. Both geographic and varietal differences may be stressed since $\mathrm{NI}$ and GE samples were produced from "Nizip Yağlık" and
"Memecik" varieties, respectively. Similar separation and allocation were observed on the score plot of combined data of fatty acid composition and phenolic profile, therefore fatty acid composition was more determinative for PCA separations than phenolic profile alone. a)
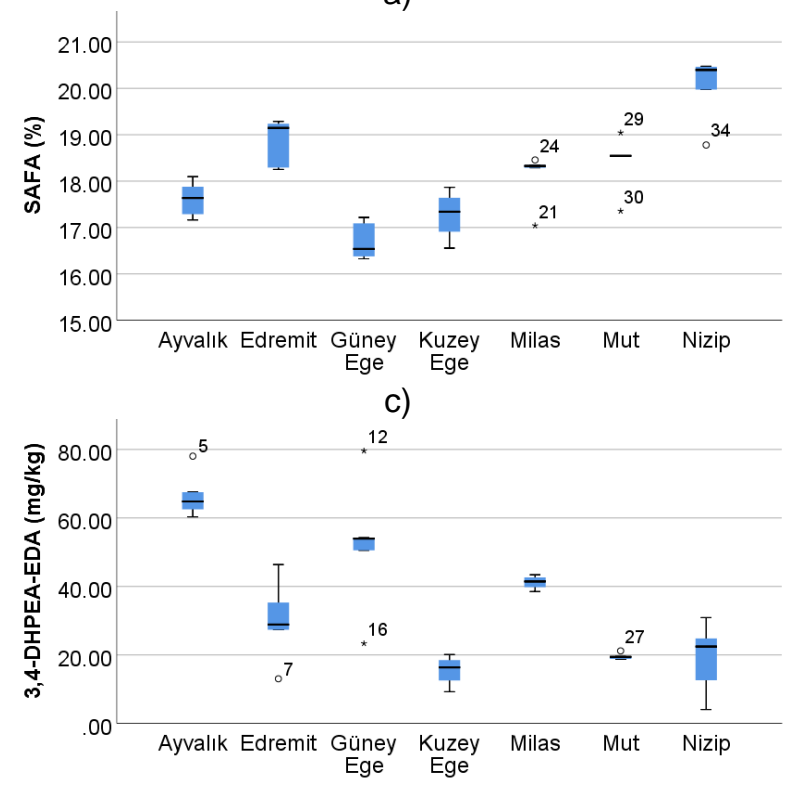

b)

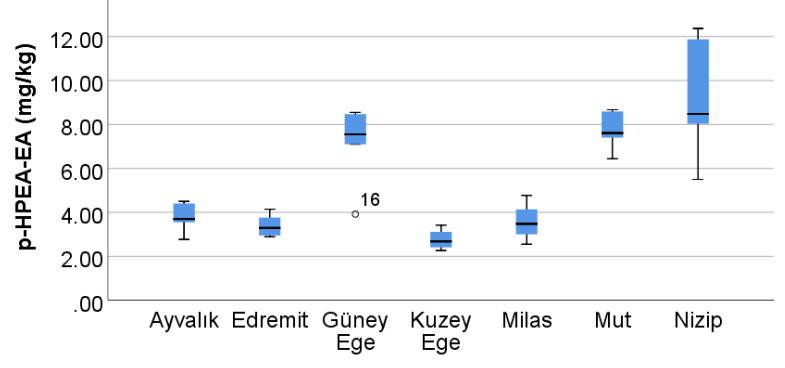

d)

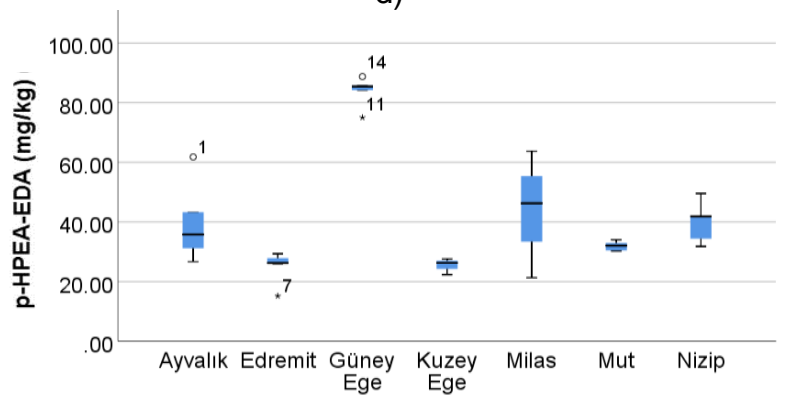

e)

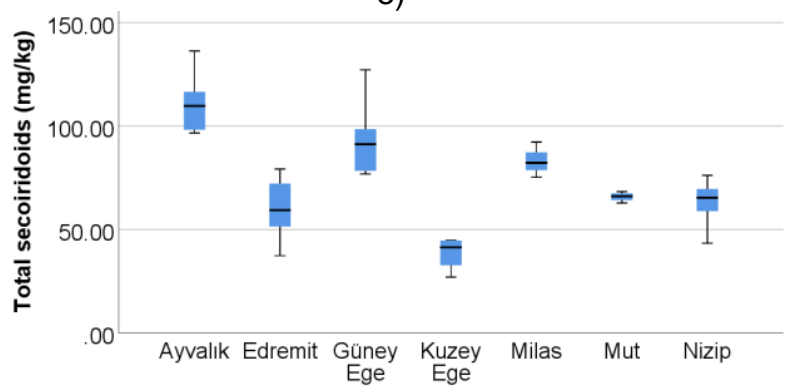

Figure 4. Box-plot graphs of main phenolics and fatty acids responsible discrimination on PCA's. Upper and lower limits of blue boxes represent ranges between first $\left(25^{\text {th }}\right.$ percentile) and third $\left(75^{\text {th }}\right.$ percentile) quartiles, whiskers represent the minimum and maximum values without outliers, and black lines located inside boxes represent medians. Outliers were presented with sample numbers on plots. SAFA: saturated fatty acids

Figure 4 represents main descriptive statistics such as min-max values, medians, and quartiles for factors most responsible for discriminations between VOO samples with Gl according to PCA's. The highest and lowest SAFA content were measured in Nizip and Güney Ege samples respectively. Ayvalık and Güney Ege samples were contained the highest total secoiridoids which is a factor of 3,4-DHPEA-EDA, p-HPEA-EDA, and p-HPEAEA. In a previous study, the fatty acid composition provided significant information to discriminate Nizip yağlık VOO's and Ayvalık samples using SIMCA, which is a multivariate method using PCA models [21]. In another study, the SIMCA, PLS-DA, and NPLS-DA models were evaluated to discriminate VOO's of arbequina variety from non-arbequina samples among 64 VOO samples. Researchers indicate that LC-DAD chromatograms provide adequate information for discrimination unless the correct data pre-processing technique was selected [36].

\section{CONCLUSION}

Phenolic profile and fatty acid composition are two factors of minor properties of VOO's. The change in variety and geographical area of the olive are two main factors determinative on the content of the composition of these variables. p-HPEA-EA, p-HPEA-EDA, 3,4DHPEA-EDA together with the total secoiridoids were 
found to be effective factors for sample groupings on PCA score plots when phenolic profile involved. Nevertheless, the fatty acid composition was found more determinant on sample separation on PCA score plots. Higher SAFA contents than $20 \%$, with one exception, in Nizip samples caused a separation from other OO's with GI. Consequently, a good separation was not achieved between Kuzey Ege, Milas, Edremit, and Ayvalık samples when fatty acid composition data involved. However, a tendency for minimal grouping, although not yet certain, maybe noted between all $\mathrm{OO}$ samples with Gl when phenolic profile data was used alone. This result shows that when it comes to the authenticity of $\mathrm{VOO}$, the profile of other minor constituents than commons such as fatty acid composition may provide more information.

\section{ACKNOWLEDGMENTS}

This study was supported by The Scientific and Technological Research Council of Turkey (TÜBITAK) under the project number of 1200872 .

\section{REFERENCES}

[1] Tsimidou, M.Z., Mastralexi, A., Özdikicierler, O. (2020). Cold pressed virgin olive oils. In Cold Pressed Oils: Green Technology, Bioactive Compounds, Functionality, and Applications, $1^{\text {st }}$ Edition, (Ed.) M.F. Ramadan, Academic Press, pp. 547-573.

[2] Vossen, P. (2007). Olive oil: History, production, and characteristics of the world's classic oils. HortScience, 42(5), 1093-1100.

[3] European Commission. (2012). Regulation (EU) No 29/2012 of 13 January 2012 on marketing standards for olive oil (codification). Official Journal of the European Union, (12), 14-21.

[4] Gıda Tarım ve Hayvancılık Bakanlığı (2017). Zeytinyağı ve Pirina Yağı Tebliği. Türk Gıda Kodeksi.

http://www.resmigazete.gov.tr/eskiler/2017/09/2017 0917-9-1.pdf (Accessed 3 February 2020)

[5] Bouarroudj, K., Tamendjari, A., Larbat, R. (2016). Quality, composition and antioxidant activity of Algerian wild olive (Olea europaea L. subsp. Oleaster) oil. Industrial Crops Products, 83, 484491.

[6] Gökçebağ, M., Dıraman, H., Özdemir, D. (2013). Classification of Turkish monocultivar (Ayvallk and Memecik cv.) Virgin olive oils from north and south zones of Aegean region based on their triacyglycerol profiles. JAOCS, Journal of the American Oil Chemist' Society, 90(11), 1661-1671.

[7] Arslan, D., Ok, S. (2020). Characterization of Turkish olive oils in details. Food Reviews International, 36(2), 168-192.

[8] Lozano-Sánchez, J., Cerretani, L., Bendini, A., Segura-Carretero, A., Fernández-Gutiérrez, A.
(2010). Filtration process of extra virgin olive oil: Effect on minor components, oxidative stability and sensorial and physicochemical characteristics. Trends Food Science \& Technology, 21(4), 201211.

[9] Ocakoglu, D., Tokatli, F., Ozen, B., Korel, F. (2009). Distribution of simple phenols, phenolic acids and flavonoids in Turkish monovarietal extra virgin olive oils for two harvest years. Food Chemistry, 113(2), 401-410.

[10] Mele, M.A., Islam, M.Z., Kang, H.M., Giuffrè, A.M. (2018). Pre-and post-harvest factors and their impact on oil composition and quality of olive fruit. Emirates Journal Food of Agriculture, 30(7), 592603.

[11] Christophoridou, S. (2017). Authentication of olive oil based on minor components. A. Kiritsakis ve $F$. Shahidi (Ed.), Olives Olive Oil as Functional Foods, pp. 555-567.

[12] Aguilera, M.P., Beltran, G., Sanchez-Villasclaras, S., Uceda, M., Jimenez, A. (2010). Kneading olive paste from unripe "Picual" fruits: I. Effect on oil process yield. Journal of Food Engineering, 97(4), 533-538.

[13] Alkan, D., Tokatli, F., Ozen, B. (2012). Phenolic characterization and geographical classification of commercial extra virgin olive oils produced in Turkey. JAOCS, Journal of the American Oil Chemist' Society, 89(2), 261-268.

[14] Gómez-Caravaca, A.M., Maggio, R.M., Cerretani, L. (2016). Chemometric applications to assess quality and critical parameters of virgin and extravirgin olive oil. A review. Analytica Chimica Acta, 913, 1-21.

[15] Ün, İ., Ok, S. (2018). Analysis of olive oil for authentication and shelf life determination. Journal of Food Science and Technology, 55(7), 24762487.

[16] Maléchaux, A., Le Dréau, Y., Vanloot, P., Artaud, J., Dupuy, N. (2019). Discrimination of extra virgin olive oils from five French cultivars: En route to a control chart approach. Food Control, 106, 106691.

[17] Likudis, Z. (2016). Olive oils with protected designation of origin (PDO) and protected geographical indication (PGI). D. Boskou ve M. L. Clodoveo (Ed.), Prod. From Olive Tree, pp. 175190. IntechOpen. Web site. https://www.intechopen.com/books/advancedbiometric-technologies/liveness-detection-inbiometrics

[18] Crizel, R.L., Hoffmann, J.F., Zandoná, G.P., Lobo, P.M.S., Jorge, R.O., Chaves, F.C. (2020). Characterization of extra virgin olive oil from Southern Brazil. European Journal of Lipid Science and Technology, 122(4), 1900347.

[19] European Commission. (2020). eAmbrosia - the EU geographical indications register. web site https://ec.europa.eu/info/food-farmingfisheries/food-safety-andquality/certification/quality- 
labels/geographical-indications-register/

(Accessed: 8 April 2020).

[20] Turkish Patent and Trademark Office (2021). Turkish products with geographical indication. Digit. GI Platf. Turkey. (Accessed 13 March 2021) https://www.ci.gov.tr/ (Accessed: 13 March 2021)

[21] Dıraman, H., Saygı, H., Hışıl, Y. (2011). Geographical classification of Turkish virgin olive oils from the Aegean Region for two harvest years based on their fatty acid profiles. JAOCS, Journal of the American Oil Chemist' Society, 88(12), 1905-1915.

[22] Dıraman, H., Saygi, H., Hisil, Y. (2011). Classification of three Turkish olive cultivars from Aegean region based on their fatty acid composition, European Food Research Technology, 233, 403-411.

[23] Gurdeniz, G., Ozen, B., Tokatli, F. (2008). Classification of Turkish olive oils with respect to cultivar, geographic origin and harvest year, using fatty acid profile and mid-IR spectroscopy. European Food Research and Technology, 227(4), 1275-1281.

[24] Kritioti, A., Menexes, G., Drouza, C. (2018). Chemometric characterization of virgin olive oils of the two major Cypriot cultivars based on their fatty acid composition. Food Research International, 103, 426-437.

[25] Maggio, R.M., Cerretani, L., Chiavaro, E., Kaufman, T.S., Bendini, A. (2010). A novel chemometric strategy for the estimation of extra virgin olive oil adulteration with edible oils. Food Control, 21(6), 890-895.

[26] COI/T.20/Doc. No 33/Rev.1 2017 Determination of fatty acid methyl esters by gas chromatography. Retrived from: https://www.internationaloliveoil.org/wpcontent/uploads/2019/11/COI-T.20-Doc.-No-33Rev.-1-2017.pdf (Accessed: 27.02.2021).

[27] COI/T.20/Doc. No 35/Rev.1 2017 Determination of peroxide value. Retrived from: https://www.internationaloliveoil.org/wpcontent/uploads/2019/11/Method-COI-T.20-Doc.No-35-Rev.-1-2017.pdf (Accessed: 27.02.2021).
[28] AOCS Cd 18-90 (2017). Official methods and recommended practices of the American oil chemists' society Method Cd 18-90. In F. Gunstone (Ed.), p-anisidine value (7th Ed). Champaign, IL: AOCS Press, USA.

[29] COI/T.20/Doc. No 19/Rev.5 (2019). Spectrophotometric investigation in the ultraviolet. Retrived from: https://www.internationaloliveoil.org/wpcontent/uploads/2019/11/Method-COI-T.20-Doc.No-19-Rev.-5-2019-2.pdf (Accessed: 27.02.2021)

[30] TGK (2014). Zeytinyağı Ve Pirina Yağı Analiz Metotları Tebliği, Tebliğ No: 2014/53, T.C Resmi Gazete Sayı: 29181. EK-9

[31] COI/T.20/Doc. No 29/Rev.1 (2017). Determination of biophenols in olive oils by HPLC. Retrived from: https://www.internationaloliveoil.org/wpcontent/uploads/2019/11/COI-T.20-Doc.-No-29Rev-1-2017.pdf (Accessed: 27.02.2021)

[32] Tasioula-Margari, M., Tsabolatidou, E. (2015). Extraction, separation, and identification of phenolic compounds in virgin olive oil by HPLCDAD and HPLC-MS. Antioxidants, 4(3), 548-562.

[33] Üçüncüoğlu, D., Sivri-Özay, D. (2020). Geographical origin impact on volatile composition and some quality parameters of virgin olive oils extracted from the "Ayvalık" variety. Heliyon, 6(9), e04919.

[34] Uluata, S., Altuntaş, Ü., Özçelik, B. (2016). Biochemical characterization of arbequina extra virgin olive oil produced in Turkey. JAOCS, Journal of the American Oil Chemist' Society, 93(5), 617626.

[35] Oğraş, Ş.Ş., Kaban, G., Kaya, M. (2016). The effects of geographic region, cultivar and harvest year on fatty acid composition of olive oil. Journal of Oleo Science, 65(11), 889-895.

[36] Jiménez-Carvelo, A.M., Cruz, C.M., Olivieri, A.C., González-Casado, A., Cuadros-Rodríguez, L. (2019). Classification of olive oils according to their cultivars based on second-order data using LCDAD. Talanta, 195, 69-76. 